\title{
Business as family, family as business: Female entrepreneurship in Kampala, Uganda
}

\begin{abstract}
Recent years have seen increased interest in entrepreneurship beyond the narrow realm of the economic. This article advances debates on the relationship between entrepreneurship and family through a longitudinal study of the experiences of female entrepreneurs in Kampala, Uganda. Drawing on a four-year panel of life history interviews, we demonstrate the value of an 'entrepreneurial life course' perspective for understanding the ways in which social and familial relations facilitate female entrepreneurship at certain junctures and restrict it at others. This perspective contributes to the literature on social embeddedness by foregrounding the temporal dimension of entrepreneurship. Furthermore, it illustrates the volatilities that characterise entrepreneurial life in urban African settings, challenging linear understandings of the entrepreneurial cycle that are based on the historical experiences of entrepreneurs in the global North.
\end{abstract}

Keywords: Entrepreneurship; Family; Gender; Kampala; Life course; Marriage; Social embeddedness; Uganda 


\section{Introduction}

Female entrepreneurship has become a key policy focus of governments and development agencies in the Global South. This trend has been accompanied both by an increased recognition of the contribution of women to economic growth, and a shift towards market-based theories of development, which reify the figure of the independent entrepreneur (Langevang et al., 2015; Minniti \& Naudé, 2010; World Bank, 2012). The latest report of the Global Entrepreneurship Monitor (GEM) (2017) shows that early stage entrepreneurial activity ${ }^{1}$ is currently highest in Africa, Latin America and the Caribbean, and that rates of female participation are higher in these regions than in Europe and North America. Nevertheless, the literature on entrepreneurship remains dominated by the experiences of white men in the Global North (Ekinsmyth 2011; Hanson 2009; Langevang et al. 2015).

A growing number of scholars have attempted to redress the gender imbalance in the entrepreneurship literature, taking their theoretical cue from a feminist vein of economic geography that rejects the separation of enterprise, household and community (GibsonGraham, 1996; Mcdowell, 2004; Oberhauser, 2002). Recent years have seen increased interest in entrepreneurship beyond the narrow economic realm and the lone figure of the (male) entrepreneur (Basu and Werbner, 2009). Work published in new fora such as the International Journal of Gender and Entrepreneurship explores the ways in which entrepreneurial activities are 'embedded' in social and familial realms, and underpinned by a range of non-commodified relationships (Ekinsmyth, 2011; Hanson, 2009; Langevang et al., 2015; Oberhauser, 2002). Within this literature, Hanson (2009) proposes a theory of entrepreneurship as a 'gendered geographic process' that links people and places through particular sets of social relations. Furthermore, Ekinsmyth (2011) demonstrates the value of a 'family embeddedness perspective' for understanding the experiences of 'mumpreneurs' in the UK. However, such studies remain largely reliant on the experiences of white female entrepreneurs in the Global North, with a few notable exceptions (Langevang et al., 2015; Minniti \& Naudé, 2010; Pasillas et al. 2017).

Studies of the economic activities of women in the Global South often locate themselves within a separate - albeit related - set of debates on the 'informal economy', which examine women's (adverse) incorporation into capitalist markets (Chant 2014; Chen 2001; Harriss-White 2010; Meagher 2011). As a result, there remains a need for contextual empirical work that "engages with the distinctiveness of women's businesses" (Ekinsmyth 2011: 106), the differences between them and the "social fabric" on which they depend (Lyons \& Snoxell, 2005: 1301). How does entrepreneurship as a gendered geographic process differ across time and space? To what extent is female entrepreneurship in the Global South embedded in the same sets of social relations as that in the Global North (e.g. the nuclear family)? What types of relationships matter for female entrepreneurs at what times and in which spaces?

This paper explores these questions through detailed empirical research in Kampala, the capital of a country that has recently been declared the most entrepreneurial in the world (Singer et al. 2015). Drawing upon an 'entrepreneurial life course' perspective, we chart the evolving relationship between women's businesses and their colleagues, households, and extended families. The following sections seek to ground this enquiry within the global and regional literatures on female entrepreneurship. A discussion of the research

\footnotetext{
${ }^{1}$ Early stage entrepreneurial activity is understood here as the percentage of the adult population (18 to 64 years) that are in the process of starting a business, or who have started a business in the past 42 months
} 
methodology is then provided, followed by an analysis of the experiences of our Ugandan participants.

\section{Grounding female entrepreneurship}

\subsection{Critical geographical perspectives}

Despite recent increases in women's business ownership worldwide, entrepreneurship remains a domain primarily associated with men (GEM, 2017; Hamilton, 2013; Hanson, 2009). Women's businesses are generally smaller, with fewer employees, lower gross sales, and less access to capital than men's (Blake, 2006; Hanson, 2009). Furthermore, their economic contributions through home-based enterprises are often ignored in official entrepreneurship surveys, or denigrated as 'self-employment' (Hanson 2009: 250). Much of the work of women continues to be relegated to the realm of 'reproduction', where its social and economic importance is obscured (Fraser, 2014). ${ }^{2}$ Consequently, "the entrepreneurial myth remains resolutely male" (Nicholson \& Anderson, 2005: 163); fixed on the transformative figure of the "heroic adventurer, individualistic, ruthless and aggressive" (Hamilton, 2013: 91).

In response, a growing number of feminist geographers have proposed critical rereadings of entrepreneurship. These readings depart from the premise that the separation of the economic and social realms of life (production and reproduction) is a product of contemporary capitalism, rather than an inevitable feature of human societies (Fraser, 2014; Gibson-Graham, 1996). Indeed, the post-war feminist project has shown that "enterprises and households are not separate 'sectors' of society, but deeply interconnected sites in a single process that is simultaneously transforming both jobs and families" (Feree et al. 1999: xxv: cited McDowell 2004: 147). Entrepreneurship is thus conceptualised as a 'gendered geographical process' that connects people and place through a diverse range of relationships and exchanges (Hanson, 2009; Oberhauser, 2002). Rather than the atomised household or enterprise, the unit of analysis thus becomes the 'household-enterprise' (Harriss-White, 2014: 984).

Scholars have subsequently advanced alternative, relational theories of entrepreneurship, drawing heavily on the concept of 'embeddedness'. Originally proposed by Granovetter (1985) as a way of navigating a middle ground between economic theories that tend to under-socialise behaviour and sociological theories that tend to over-socialise it, this concept premises that all economic activities are 'embedded' within social relationships, and cannot be meaningfully understood in isolation. Applied in studies of entrepreneurship, the concept has helped demonstrate the ways in which entrepreneurial activities are embedded in households, families, and social relationships (Aldrich \& Cliff, 2003; Ekinsmyth, 2011; Jack \& Anderson, 2002; Langevang et al., 2012; 2015). Of particular relevance to the study of female entrepreneurship here is the work of Ekinsmyth (2011) and Langevang et al. (2012).

First, Ekinsmith (2011) demonstrates the continued relevance of Aldrich and Cliff's (2003) 'family embeddedness perspective' for understanding the aspirations and practices of 'mumpreneurs' in the UK. Although their enterprises grew out of the restrictive spaces of UK family life (e.g. mothers' social groups), she shows that these women are breaking down gender boundaries by shifting "intimate forms of domestic, sociable and work encounters" into the public sphere (Bauman 1989: 178). Second,

\footnotetext{
${ }^{2}$ Fraser argues that in a world 'where money is a primary medium of power, the fact of its being unpaid [or poorly paid] seals the matter' (2014: 62)
} 
Langevang et al. draw upon an expanded 'social embeddedness' perspective' to explore how the entrepreneurial motivations of young men and women in Uganda are "intertwined with changes in the socio-economic environment", including social networks and family relations (2012: 439). Critically, their approach emphasises the influence of a broad range of relationships that transcend the (nuclear) family.

Often missing within this relational literature on entrepreneurship, with its emphasis on embedded relationships and institutions, is a sense of the temporal dimension of entrepreneurship, and the ways in which different relations matter at different times and in different spaces. We seek to restore this temporal dimension by proposing a longitudinal, 'entrepreneurial life course' perspective that socialises narrow conceptualisations of the entrepreneurial cycle, and situates them within the context of the life course of female entrepreneurs in Uganda. Similar perspectives has been deployed in recent studies of entrepreneurship in the global North (see e.g. Jayawarna et al. 2011; 2014; Schoon \& Duckworth, 2012) and to a lesser extent the global South (e.g. Langevang et al. 2012), albeit without the use of qualitative panel data (see methodology). Drawing inspiration from these approaches, our framework proposes to examine changes in the entrepreneurial cycle, such as the shift from the 'prelaunch' (opportunity) to the 'launch' (development) phase (Baron 2007: cited Frese and Gielnik, 2014: 414), alongside changes in the life course, such as education, marriage and childbirth. The unit of analysis is thus the household-enterprise (Harriss-White 2014). This approach enables the identification of the different times in which different forms of embeddedness matter for female entrepreneurs.

Within this framework, we adopt an expanded definition of entrepreneurship that extends beyond the heroic male 'adventurer' to include anyone who "owns a business, assumes the risks associated with ownership, deals with the uncertainties of coordinating resources and is in charge of day-today-management of the business" (Hanson 2009: 251), bringing into focus the activities of a group of women who are under-represented in the entrepreneurship literature (Ekinsmyth, 2011; Lyons \& Snoxell, 2005b).

\subsection{Entrepreneurship and policy in the Global South}

The promotion of female entrepreneurship has become a key policy focus among governments and development agencies in the Global South, believed to create employment, reduce poverty, and improve wellbeing (Langevang et al., 2015; Minniti \& Naudé, 2010; World Bank, 2013). ${ }^{3}$ This objective is pursued through a range of initiatives including access to education, skills and credit, designed to remove the socioeconomic barriers experienced by female entrepreneurs (De Mel et al. 2009; Grimm et al. 2013; van Rooyen et al. 2012). However, despite evidence of improved economic outcomes in certain settings (Ganle et al. 2015), such initiatives have been criticised for indebting large numbers of women, damaging their social relationships and (in some cases) displacing them from their communities (Meagher 2005; Bateman 2014). Scholars have critiqued market-based models of development for undermining the role of the state and emboldening private sector interventions that place little value on the lives of small-scale producers and traders (Ferguson 2015: 10). Indeed, Bhattacharya (2014: 959) argues that a singular focus on entrepreneurship "obfuscates the exploitative and alienating processes at work and displaces the agenda of radical subjectivity and labour rights".

While the current policy emphasis on female entrepreneurship has worked to promote and amplify the productive activities of women and thus de-centre masculine narratives

\footnotetext{
${ }^{3}$ This has not always been the case, as the following section shows for the case of Kampala
} 
of entrepreneurship (Hamilton 2013), it has relatively little to say about women's continued involvement in reproductive activities, and the contribution of these activities to economic growth. Geographers have shown that in many regions of the world, women's increased participation in entrepreneurial activities has had no significant effect on household divisions of labour, resulting in a 'double burden' of paid and unpaid labour (Chant, 2014; Evans, 2016; Harriss-White, 2010; Langevang et al. 2015).

In sub-Saharan Africa, women are less likely to be recognised as business owners than men (Chen, 2001, cited Monteith \& Giesbert, 2016) and more likely to face additional barriers to accessing credit through formal sources (Chirwa, 2008; Kuada, 2009). Women often navigate these barriers by cultivating social relationships that enable them to leverage additional resources (Kuada, 2009). For example, Langevang (2008) uses the example of 'Aisha' to show how young informal entrepreneurs in Accra require support from 'big men' to pursue otherwise marginal enterprises. In the remainder of this subsection we briefly review the challenges faced by female enterprises due to 'the differing effects of the complex, multiple, and shifting layers of institutional contexts in which they are embedded' (Langevang et al. 2015: 449), and the importance of their social networks in addressing these.

Langevang et al.'s (2015) study of female entrepreneurs in Ghana reveals a disjuncture between positive societal attitudes towards female entrepreneurs, and enterprises that are characterised by vulnerability and relatively low levels of achievement. Some of these challenges are dealt with through mobilising different sorts of networks; for example, Hanson (2005) shows how connections through household, kin, neighbourhood, occupation, alumni and religious associations are used in urban Ghana to increase opportunities and protect against economic uncertainty. Similarly, Frayne (2004) emphasises the importance of rural-urban family ties for the urban poor in Windhoek, Namibia. Meanwhile, Lyons and Snoxell find that female entrepreneurs survive by cycling through different enterprises, frequently changing the goods and services that they sell in line with evolving structures of opportunity and demand (2005a).

Female entrepreneurs in particular use community ties to counterbalance the obligations that strong extended family ties create, which might otherwise reduce their opportunities to experiment relative to male entrepreneurs. For example, Ntseane (2004) and Clark (1994) show that success within the informal sector in Botswana and Ghana respectively is dependent on social networks, or more specifically, 'egalitarian multilateral relations' (Clark 1994: 217) that are undermined by the downward pressure on incomes created by financial crises (ibid; Overa, 2007). Similarly, Elyachar (2010) demonstrates how women in Cairo use acts of movement, conversation and visitation to create 'communicative channels' through which resources such as information, goods and emotions can flow, enabling their survival in the absence of state support (ibid.: 459). Describing similar forms of dependency and redistribution in South Africa, James Ferguson writes that economic survival "is less about producing goods and services than it is about securing distributive outcomes. It is in large measure about accessing or making claims on the resources of others" (2015: 94).

On the one hand, framing women's entrepreneurial success in terms of their access to external networks - commodified as 'social capital' - fails to acknowledge the interdependencies between the enterprise and the household emphasised in the feminist scholarship. On the other hand, relational approaches such as the 'family embeddedness' perspective tend to assume the existence of a relatively stable set of social relations, based on the experiences of female entrepreneurs in the Global North (Aldrich \& Cliff, 2003; Ekinsmyth, 2011). Missing in both approaches is a sense of the temporal dimension of female entrepreneurship, and the various forms of dependency, mobility and volatility 
that characterise entrepreneurial life in urban African contexts (Di Nunzio, 2015; Simone 2004; Weiss 2009). In response, we apply a broader, 'mixed embeddedness' framework (Langevang et al. 2015) in order to examine the times and spaces in which a broad range of social relationships - including kin, spouses and colleagues - matter for female entrepreneurs at different stages of the entrepreneurial life course in Kampala.

\section{Entrepreneurship in Kampala: A gendered history}

The regional challenges of urbanization, informalization, and a youthful population are evident in Uganda. The country was recently declared the most entrepreneurial in the world (Singer et al. 2015), with one of the youngest populations, ${ }^{4}$ and fastest-growing capital cities. ${ }^{5}$ Rosa writes that the average entrepreneur in Uganda is "female, 18-34 years of age, [...] working in the consumer service sector" (Rosa 2014). This observation is supported by statistics on the evolving gender composition of Kampala (see Table 1), and studies that emphasise the predominance of women in the city's informal economy (Wallman 1996; Wallman \& Pons 2001). As in other African contexts, Women predominate in the small scale informal sector (Chen et al., 2016; Minniti \& Naudé, 2010) and in specific sectors such as hairdressing and tailoring (Langevang and Gough, 2012). Nevertheless, they continue to be disadvantaged by gendered roles and institutions that have a long history in the region.

Kampala is located in Buganda, a subnational kingdom that encompasses the Central region of Uganda. Women in the kingdom have long relied on entrepreneurial activities in order to evade demands placed on them by patriarchal institutions. Women seeking to escape marriage in precolonial Buganda were allocated a place to live by local chiefs on the understanding that they would assist other wives. Such women were known as banakyeombekedde ('free women') whose work was not stigmatised on account of the fact that it was for other women, rather than for unmarried men (Davis 2000). This category was differentiated from that of the bakirerese ('restless people'), who were understood to be transient men or women who would move between dependant relationships rather than seek independence (ibid.). Obbo (1980) argues that female bakirerese were highly mobile, and often returned to their villages with new ideas, clothes and methods of food preparation; entrepreneurial attributes that remain valuable in the contemporary informal economy. However, unlike the banakyeombekedde, the bakirerese were stigmatised on account of the fact that they used sex to achieve economic goals and performed domestic duties for men to whom they were not married (Davis 2000). These roles underline the historical interplay between marriage and entrepreneurship in the region, and its impact on the mobility of women.

The early colonial period brought with a reification of 'domestic virtue' as a female moral ideal, through which women were 'valued for their contributions within the family' and expected to be 'submissive and deferential' to men (Bantebya-Kyomuhendo \& McIntosh 2006: 2). However, in practice, women resisted and re-interpreted this ideal. Still under considerable social pressure to get married, a number of women decided to combine being a wife with becoming an economically independent landowner, increasing instances of marital dispute and separation (Obbo 1980). Consequently, a new group of landowning banakyeombekedde emerged, many of whom moved to town in order to boost their income, adapting their skills to work in new commercial arenas through the

\footnotetext{
4 Uganda has the second youngest population in the world, according to Euromonitor (2012).

${ }^{5}$ Kampala is projected to continue growing at an annual rate of $4 \%$ until 2020 , making it the $13^{\text {th }}$ fastest growing urban area in the world, according to CityMayors

(http://www.citymayors.com/statistics/urban growth1.html, downloaded 14/09/18)
} 
provision of cooked food, produce, milk and beer.

Southall and Gutkind (1957) observed the rise of 'mukwano relationships' (friendship unions) alongside 'formal marriages' (performed according to custom or religion) and 'free marriages' (long-term cohabitation) in the late colonial period. Mukwano relationships were understood to be temporary and involved greater degrees of negotiation, for example over what forms of domestic labour were to be performed for what amounts of money. Nevertheless, the colonial category of the 'town woman' began to be used in contradistinction to that of the 'proper woman' in the rural homestead in an attempt to control the movements and entrepreneurial activities of women (Davis 2000; Ogden 1996). Consequently, women were in the minority in colonial Kampala (Table 1).

The political and economic disruptions that followed Uganda's independence (1962) created new opportunities and challenges for women in the capital. While the economic crises of the 1970s plunged a large number of women into poverty, Feminist scholars have argued that they also created spaces in which women to assert 'a legitimate claim on the cash economy' (Ahikire \& Ampaire, 2003: 28). The population of Kampala doubled between 1969-1991, during which the proportion of female inhabitants increased from $45 \%$ to $51 \%$ (Table 1). The collapse of the formal economy led to compensatory developments in the informal economy which tended to favour women (Wallman \& Pons 2001: 123). Female entrepreneurs began trading from their households, on footpaths and roads, in the passageways between city buildings (bikuubo), and in open-air markets (Monteith 2017). Furthermore, they created new urban infrastructures, including the female night market, or toninyira mukange ('don't step in mine'); a place where women pursue "aggressive mini-capitalist ventures", selling food by the light of paraffin lanterns (Musisi 1995: 128).

Table 1: Kampala's female population over time

\begin{tabular}{|l|l|l|}
\hline Year & Female population of Kampala & \% of total \\
\hline 1959 & Unknown & $30^{6}$ \\
\hline 1969 & 329,497 & 45 \\
\hline 1980 & 458,503 & $49^{7}$ \\
\hline 1991 & 774,241 & 51 \\
\hline 2001 & $1,189,142$ & 52 \\
\hline 2014 & $1,516,210$ & 52 \\
\hline
\end{tabular}

Throughout this period, marriage remained an important institution in which the entrepreneurial activities of African women were embedded. However, women also forged a variety of alternative and additional channels of support. De Boeck and Plissart argue that a majority of the social networks and daily strategies of survival in contemporary African cities are "the work of women and mothers", and that their development has been accompanied by an erosion of male authority (De Boeck \& Plissart, 2004: 190). An elder female entrepreneur in Monteith's (2017: 12) study in Kampala explained:

Today, if a man tells you not to work, you just pack your bag and go, but before he could say 'no'.

Nevertheless, Ugandan women continue to be disadvantaged in their entrepreneurial activities by restricted access to secondary schooling and technical and vocational

\footnotetext{
6 Parkin 1969: 6

7 Ibid.
} 
education. ${ }^{8}$ Furthermore, they are required to combine entrepreneurial activities in the informal economy with various forms of unpaid domestic labour, and contribute disproportionately to household food, health and education (Bantebya-Kyomuhendo \& McIntosh, 2006; Snyder, 2000; Wallman, 1996). Snyder (2000) has shown that while female entrepreneurs in Uganda tend to prioritise their children and family in their expenditure, male entrepreneurs tend to retain a large proportion of their income for personal use. We developed a methodology designed to explore the extent to which female entrepreneurs are able to overcome these constraints by drawing upon different relationships and resources at different stages of their entrepreneurial life course.

\section{Methodology}

The recent emergence of narrative accounts and life history interviews (LHIs) in the entrepreneurship literature provides an important counterbalance to the historical dominance of quantitative enquiries that tend to supress "the more silent, feminine personal end" of entrepreneurship (Bird \& Brush 2002: 57, cited Ekinsmyth 2011: 107). ${ }^{9}$ Nevertheless, one of the limitations of LHIs is that they tend to produce neatly-honed accounts anchored in an 'overarching narrative structure' that conceals the complexities and contradictions of life as it is lived (Staples, 2014: xxi; see also Shacklock \& Thorp 2004). Furthermore, single interviews inevitably generate a compressed sense of time, in which separate events and circumstances bleed into one another. Consequently, longitudinal methods provide an important basis for disturbing the neat narratives generated by single LHIs, capturing experiences of entrepreneurship as they are lived by women in places such as Kampala.

The article draws upon a four-year panel of interviews with an opportunistic sample of 12 women in order to investigate the temporal dimension of entrepreneurship as it unfolds in the lives of female entrepreneurs in Kampala, Uganda. These women were selected from a larger, random sample of entrepreneurs in the small-scale informal sector surveyed as part of a project funded by the German Development Bank (KfW). ${ }^{10} \mathrm{~A}$ total of 20 female entrepreneurs were interviewed as part of the KfW project in 2012, purposefully sampled in order to ensure a broad range of entrepreneurial activities (e.g. hairdressing, market vending, tailoring). From this original group, we were able to locate 12 entrepreneurs for follow-up interviews in 2013 and 2015 (see Table 2). We conducted life history interviews with the assistance of a small team of Ugandan researchers, focusing on the career trajectories of the 12 women, and the resources, skills and relationships they were able to draw upon at different stages of establishing and developing their businesses.

The characteristics of the sample are summarised in Table 2. In terms of their enterprises, they reported working between 45 and 91 hours per week and earning between 5,000 (US\$1.43) and 300,000 Ugandan Shillings (US\$85.71) per week. ${ }^{11}$ Seven entrepreneurs

\footnotetext{
${ }^{8}$ Girls' enrolment at secondary school in Uganda has consistently lagged behind boys (currently by 8\%). http://unesdoc.unesco.org/images/0024/002457/245752e.pdf

${ }^{9}$ See for example, Ekinsmyth 2011; Langevang, 2008; Langevang \& Gough, 2012; and the special issue of International Development Planning Review edited by Gough, Langevang \& Owusu 2013. In a recent review of the three highest ranking entrepreneurship journals, Hlady-Rispal \& Jouison-Laffitte (2014) show that only 15 per cent (of 732) studies deployed a qualitative methodology.

10 This was the Employment, Empowerment and Living Standards project hosted at the German Institute of Global and Area Studies (GIGA). 5,000 enterprises were listed across the city in 2012, of which 1,000 were randomly sampled for household and enterprise surveys

${ }^{11}$ Currency conversion correct at time of fieldwork in August 2015 (US\$ = USh 3,500)
} 
reported having a bank account and two of those who didn't have a bank account participated in either a Savings and Credit Cooperative Organisation (SACCO) or Rotating Savings and Credit Association (ROSCA). A third of our participants changed their main occupation over the course of the three-year interview panel and a quarter changed their spouse, supporting our methodological emphasis on mobility and flux. 
Table 2: Research participants

\begin{tabular}{|c|c|c|c|c|c|c|c|c|c|}
\hline \multirow[t]{2}{*}{ No. } & \multirow[t]{2}{*}{ Pseudonym } & \multirow[t]{2}{*}{ Education } & \multirow{2}{*}{$\begin{array}{l}\text { Age } \\
2012 \\
\end{array}$} & \multicolumn{3}{|c|}{ Marital status } & \multicolumn{3}{|l|}{ Main occupation } \\
\hline & & & & 2012 & 2013 & 2015 & 2012 & 2013 & 2015 \\
\hline 1 & Hadija Nikuze & Started primary & 28 & $\begin{array}{l}\text { Married } \\
\text { (polygamy) }\end{array}$ & $\begin{array}{l}\text { Married } \\
\text { (polygamy) }\end{array}$ & \begin{tabular}{|l|} 
Married \\
(polygamy)
\end{tabular} & $\begin{array}{l}\text { Market vendor } \\
\text { (produce) }\end{array}$ & $\begin{array}{l}\text { Market vendor } \\
\text { (produce) }\end{array}$ & $\begin{array}{l}\text { Market vendor } \\
\text { (produce) }\end{array}$ \\
\hline 2 & Janet Mukamwezi & Started primary & 31 & $\begin{array}{l}\text { Married } \\
\text { (polygamy) }\end{array}$ & $\begin{array}{l}\text { Married } \\
\text { (polygamy) }\end{array}$ & Separated & $\begin{array}{l}\text { Cooked food } \\
\text { restaurant }\end{array}$ & Dairy shop & Retail of dairy \\
\hline 3 & Rose Mbagudde & $\begin{array}{l}\text { Completed } \\
\text { primary }\end{array}$ & 32 & $\begin{array}{l}\text { Married } \\
\text { (monogamy) }\end{array}$ & $\begin{array}{l}\text { Married } \\
\text { (monogamy) }\end{array}$ & $\begin{array}{l}\text { Married } \\
\text { (monogamy) }\end{array}$ & $\begin{array}{l}\text { Fabric } \\
\text { wholesale }\end{array}$ & Poultry feed & $\begin{array}{l}\text { Poultry feed } \\
\text { business }\end{array}$ \\
\hline 4 & Monica Awor & $\begin{array}{l}\text { Completed O- } \\
\text { level }\end{array}$ & 26 & Single & Single & Single & $\begin{array}{l}\text { Market vendor } \\
\text { (fish) }\end{array}$ & $\begin{array}{l}\text { Market vendor } \\
\text { (fish) }\end{array}$ & $\begin{array}{l}\text { Market vendor } \\
\text { (fish) }\end{array}$ \\
\hline 5 & Mariam Mutesi & $\begin{array}{l}\text { Completed 0- } \\
\text { level }\end{array}$ & 23 & $\begin{array}{l}\text { Married } \\
\text { (monogamy) }\end{array}$ & $\begin{array}{l}\text { Married } \\
\text { (monogamy) }\end{array}$ & $\begin{array}{l}\text { Married } \\
\text { (monogamy) }\end{array}$ & $\begin{array}{l}\text { Market vendor } \\
\text { (produce) }\end{array}$ & $\begin{array}{l}\text { Market vendor } \\
\text { (produce) }\end{array}$ & $\begin{array}{l}\text { Market vendor } \\
\text { (produce) }\end{array}$ \\
\hline 6 & Juliet Nakiwala & $\begin{array}{l}\text { Completed 0- } \\
\text { level }\end{array}$ & 37 & $\begin{array}{l}\text { Married } \\
\text { (monogamy) }\end{array}$ & $\begin{array}{l}\text { Married } \\
\text { (monogamy) }\end{array}$ & $\begin{array}{l}\text { Married } \\
\text { (monogamy) }\end{array}$ & Tailor & Tailor & Tailor \\
\hline 7 & Aidah Nassozi & $\begin{array}{l}\text { Completed } \\
\text { primary }\end{array}$ & 26 & Divorced & Divorced & Divorced & Tailor & Tailor & Tailor \\
\hline 8 & Joan Nyamugisha & $\begin{array}{l}\text { Completed } \\
\text { primary }\end{array}$ & 24 & $\begin{array}{l}\text { Married } \\
\text { (monogamy) }\end{array}$ & $\begin{array}{l}\text { Married } \\
\text { (monogamy) }\end{array}$ & Divorced & $\begin{array}{l}\text { Market vendor } \\
\text { (produce) }\end{array}$ & $\begin{array}{l}\text { Market vendor } \\
\text { (produce) }\end{array}$ & \begin{tabular}{|l|} 
Market \\
wholesaler \\
(produce)
\end{tabular} \\
\hline 9 & Regina Mukalubiga & $\begin{array}{l}\text { Completed } \\
\text { primary }\end{array}$ & 31 & $\begin{array}{l}\text { Married } \\
\text { (monogamy) }\end{array}$ & Divorced & $\begin{array}{l}\text { Remarried } \\
\text { (monogamy) }\end{array}$ & $\begin{array}{l}\text { Market vendor } \\
\text { (plastics) }\end{array}$ & $\begin{array}{l}\text { Market vendor } \\
\text { (plastics) }\end{array}$ & $\begin{array}{l}\text { Market vendor } \\
\text { (plastics) }\end{array}$ \\
\hline 10 & Scovia Mbabazi & $\begin{array}{l}\text { Completed 0- } \\
\text { level }\end{array}$ & 38 & $\begin{array}{l}\text { Married } \\
\text { (monogamy) }\end{array}$ & $\begin{array}{l}\text { Married } \\
\text { (monogamy) }\end{array}$ & $\begin{array}{l}\text { Married } \\
\text { (monogamy) }\end{array}$ & $\begin{array}{l}\text { Hairdressing } \\
\text { salon }\end{array}$ & $\begin{array}{l}\text { Hairdressing } \\
\text { salon }\end{array}$ & $\begin{array}{l}\begin{array}{l}\text { Hairdressing } \\
\text { salon }\end{array} \\
\end{array}$ \\
\hline 11 & Amina Sserwanga & $\begin{array}{l}\text { Bachelor's } \\
\text { degree }\end{array}$ & 26 & $\begin{array}{l}\text { Married } \\
\text { (monogamy) }\end{array}$ & $\begin{array}{l}\text { Married } \\
\text { (monogamy) }\end{array}$ & $\begin{array}{l}\text { Married } \\
\text { (monogamy) }\end{array}$ & $\begin{array}{l}\text { Husband's } \\
\text { electronics shop }\end{array}$ & $\begin{array}{l}\text { Husband's } \\
\text { electronics shop }\end{array}$ & \begin{tabular}{|l|} 
Husband's \\
electronics shop
\end{tabular} \\
\hline 12 & Agnes Uwamahoro & $\begin{array}{l}\text { Completed A- } \\
\text { level }\end{array}$ & 27 & $\begin{array}{l}\text { Married } \\
\text { (monogamy) }\end{array}$ & $\begin{array}{l}\text { Married } \\
\text { (monogamy) }\end{array}$ & $\begin{array}{l}\text { Married } \\
\text { (monogamy) }\end{array}$ & $\begin{array}{l}\text { Market vendor } \\
\text { (produce) }\end{array}$ & $\begin{array}{l}\text { Market vendor } \\
\text { (produce) }\end{array}$ & Housewife \\
\hline
\end{tabular}


Interviews were conducted in Luganda by the Ugandan research team and translated into English. One of the authors was present at the majority of the interviews and there were lengthy debriefing sessions at the end of each day where they talked through the interview content with the researchers. As the same researchers were involved throughout, we were able to follow up on concerns raised in previous rounds, which we did by re-reading each individual's dataset prior to interview and generating a small number of focused questions. We also benefitted from the rapport generated between researchers and participants over the course of the four years. The verbatim transcripts were then analysed thematically and as individual case studies in order to explore the influence of different relationships and challenges at different points in the entrepreneurial life course. Inductive codes were applied to the transcripts to denote $i$ ) periods in the entrepreneurial life course, ii) socioeconomic challenges and opportunities, and iii) forms of support and embeddedness.

\section{Female entrepreneurship in Kampala: three phases}

The analysis that follows is organised around three temporal phases derived from the testimonies of female entrepreneurs in Kampala, which are broadly analogous to the entrepreneurial life cycle as understood in the conventional literature: pre-launch (opportunity identification), launch (development and execution) and post-launch (consolidation and expansion) (Baron 2007, cited Frese \& Gielnik 2014: 414). However, these phases are adapted in line with the life course approach outlined above; for example, the pre-launch phase is extended to incorporate the role of a broad range of structural factors and formative influences that shaped the entrepreneurial decisions of women years before their entry into the urban economy. Likewise, the post-launch phase includes a discussion of different forms of pluriactivity and diversification that were often facilitated by marital breakdown. We do not present these three phases as a universal model, but rather an ideal type that provides a point of departure (and critique) for the analysis. Indeed, this cycle was often interrupted, reversed and/or re-started by female entrepreneurs in Uganda, as we demonstrate below.

The remainder of this section focuses on the ways in which female entrepreneurs navigate each phase by drawing upon different relationships at different times and in different spaces, illustrating the relationship between different stages of the entrepreneurial cycle and different forms of embeddedness. While a broad variety of relationships were important at all stages, we demonstrate the significance of three particular relations during the three phases of the entrepreneurial life cycle: extended families, spouses and colleagues.

\subsection{Pre-launch: the role of extended family}

The entrepreneurial journeys of female entrepreneurs in Uganda started long before their arrival in Kampala, shaped by gender roles, family networks, and the cost of education. The childhoods of our participants were punctuated with movements between different schools and households, regulated by extended family networks. As Miriam explained:

I stayed with my mother until I was three years old. Then I was taken to Rubaga to stay with my Aunt, where I studied nursery, primary one and primary two. Then I was taken back to Jinja to return to my mother and my father. I studied up to primary 7 from Jinja. Then I was taken to Busia to stay with my grandparents where I studied senior 1 and 2. I was then brought back to Jinja for senior 3 and senior 4. My father passed away when I was in senior 3, so my aunt's husband 
paid my school fees for senior 4 . After senior 4 I went to Kayunga to stay with my uncle and began selling clothes in his shop. (Miriam)

These movements took Miriam from the suburbs of Kampala over 200 kilometres East (to Busia) and then back again. Such high levels of childhood mobility were not uncommon; for example, Janet, who was born to Tanzanian parents, was educated in three different countries. This mobility was partly explained by the fact that fewer than half of the participants still had both parents, and ill-health often preceded family breakdown. However, mobility was also a strategy in pursuit of education. For example, Rose describes how she stayed for different periods with her grandparents and aunt and uncle owing to their willingness to pay for her school fees. Her education ended when her aunt had a 'marital misunderstanding' with her uncle and left the marriage. The figure of the maternal aunt played an important role in the education of a number of participants. Juliet described how she was supported by her aunt until she "no longer had money because she had to pay fees for the younger ones... and felt bad about it."

Such testimonies demonstrate the existence of a gendered division of education and care in Uganda, through which women were much more likely to receive support for their education from female members of the family; a trend that many of them would experience again in their attempts to educate their own children (see below). Referring to her experiences and those of her female siblings, Rose claimed that "our parents deliberately refused to educate us", illustrating the continuation of historical barriers to the education of girls in Uganda. Only half of the entrepreneurs completed secondary education, ${ }^{12}$ although one (Amina) obtained a Batchelor's degree with family support (see Table 2). All our participants underwent a similar process of migration to the capital triggered by the end of their education. This migration was motivated by a combination of opportunity (e.g. an offer of occupational training) and, more frequently, constraint (e.g. the absence of paid work in rural areas), negotiated either through work or marriage. Monica explained that began to work in on a market stall from the age of thirteen as her father's work in the stone quarry was 'not bringing in enough money' to support her younger siblings.

On the one hand, a number of our participants saw entrepreneurship as a way to avoid impending marriage. For example, Aidah explained how her parents had proposed that she start a tailoring business only after "they had brought the idea of getting me a man to get married but [I told them] I didn't want to get married". Young women were unlikely to be permitted by their family to work alone or with unmarried men (the role of the precolonial bakirerese) and so maternal aunts played an important role in mediating their entry into the urban economy. Scovia, Joan, Rose, Aidah and Juliet all found work through an aunt. Joan explained that her aunts each took one of her and her four siblings following the separation of her parents 'to help them in their respective homes'. Young women thus often had little choice over their initial profession; for example, Juliet explained that she wanted to do catering but her aunt persuaded her to work in tailoring, even though "I told her that I did not like sewing".

On the other hand, participants saw marriage as a way to address the resource constraints of unemployment. As Regina explained: "the situation is bad when you are not working... for instance when you want something and you can't get it - that is what forced me to get married". Other women were 'forced' to get married by their family; for example, Mariam was told by her parents to leave her childhood home after she become pregnant, and to

\footnotetext{
12 To put these figures in context, according to UNESCO GMR (2015), 23\% completed lower secondary and $16 \%$ upper secondary.
} 
move in with the father of the child in Kampala. Marriage in this sense was understood as a form of co-habitation or 'friendship union' - usually in Kampala's sprawling suburbs without an official introduction or ceremony, due to the significant costs of such events. ${ }^{13}$ Early marriages were often unsuccessful, and five of our participants (42\%) separated from their spouses before or during the research process. For example, Rose's ex-husband abandoned her and their three children in his brother's house, who then evicted them for non-payment of rent. Similarly, Janet separated from her husband when she was two months pregnant with their fifth child. Rather than contribute to their upkeep, he took four of the five children with him to a new relationship.

The above experiences may be considered part of an extended 'pre-launch' phase, during which the skills, motivations and formative influences of entrepreneurs are established. For many young women in Uganda, entrepreneurship emerged as a strategy in pursuit of a cash income following the end of their formal education in order to support younger siblings and/or children. This strategy often included a deliberate evasion of patriarchal institutions, such the marital home, akin to that deployed by the 'free women' (banakyeombekedde) of precolonial Buganda (Davis 2000). In their place, participants relied on extended family networks, and, in particular, matriarchal aunts, who often brokered their entry into the cash economy. These female extended family relations largely absent from the literature in the global North - subsequently reproduced gendered divisions of entrepreneurship; for example, through the prioritisation of tailoring and hairdressing over other sectors (Langevang \& Gough 2012).

In the language of the entrepreneurship literature, 'opportunity identification' was thus shaped by structural constraints including gender roles, limited access to education and diminishing household incomes, but also by the possibilities provided through female extended family networks. Family embeddedness was thus of critical importance in the pre-launch phase, and in order to achieve early entrepreneurial success, women were required to combine supportive family networks with access to capital and dynamic (urban) economic spaces. In the absence of these conditions, many of our participants turned to marriage in order to consolidate their resources prior to launching their own enterprises.

\subsection{Launch: the role of spouses}

Our participants' early experiences in Kampala was shaped by the times and spaces through which they entered the city, and the relationships and resources they were able to draw upon on arrival. Unmarried women consequently relied on the connections provided by female family members:

I decided to sell fish since that's what my mother used to sell and she was well known here for that, so I said 'let me go and keep those customers', and secondly, I had experience [of] selling it because our mother used to call us to help her whenever she would be going somewhere... So the training has to start early and your parent is the one to show you what to do (Monica)

Here Monica's mother played an instrumental role in the launch of her enterprise through the provision of training and, more significantly, a stable customer base in a highly-

\footnotetext{
13 Aidah explained of her marriage: "we didn't officially go to the parents, as you know here in Kampala when you get someone you say you will visit the parents later." Such unions resembled the 'free marriage' model described by Southall and Gutkind in late colonial Kampala (1957).
} 
competitive economy in which 'customer care' and retention is a key attribute of success (Monteith \& Giesbert 2016). In line with the findings of Gough (2010) and Langevang et al. (2012), the intergenerational transfer of entrepreneurial skills and aspirations were thus important components of young women's decision to launch their own businesses or take over those owned by elder family members.

In the absence of such entrepreneurial connections, unmarried women often began life in Kampala as domestic labourers in the households of female relatives; a historical role performed by young women in the city (Wallman \& Pons 2011). However, such activities often formed part of a longer-term strategy to raise enough capital to start a business. This strategy also often involved marriage. For example, Hadija explained that she worked as a house girl for her mother in Kampala while looking to 'get a man to marry me', and started her first business shortly after getting married. Similarly, Janet established her own businesses soon after marriage:

I came [to Kampala] with my husband with intentions of looking for jobs so as to earn a living and survive. He was doing his own work and I too started my own job. My friends helped because when I was starting, I didn't have money... my husband used to come to Kampala and he saw opportunities were there for business (Janet)

A friend subsequently found Janet a space in which she could sell cooked food which she rented with capital provided by her husband. All of our participants except one (Monica) were married at the point of launching their first enterprise. In this way, marriage was valued by women insofar as it was seen to provide access to resources and networks outside of the confines of kinship, generating new opportunities for entrepreneurship. Indeed, in the absence of family networks that provided access to entrepreneurial opportunities, marriage was often seen as a precursor to establishing a business:

I didn't get anything from my marriage but I learnt a lot from it... I learnt that for someone to survive, the first thing you have to do is fight for yourself... If it were not for the job of marriage, I wouldn't have learnt the other jobs (Aidah)

For Aidah, marriage and entrepreneurship were both comparable to 'jobs' requiring of considerable personal endeavour. Indeed, participants often evaluated their partners and their businesses in similar, instrumental ways; stating, for example, "he has contributed towards the basic necessities at home" (Janet), or "there was nothing he was helping me with" (Hadija). Bad marriages were seen to constrain women's mobility and earning potential, leaving them with 'nothing to do' (Monica). Consequently, such scenarios were actively resisted:

Before starting the stall, I used to sit at home. Then I told [my husband] that I was tired of sitting at home. I told him I had seen people making a profit from selling jackfruit. So I asked if he could get 5,000 shillings (US\$1.43) so that I could buy one fruit and start from there. (Hadija)

Hadija thus convinced her husband to provide the start-up capital for her market business shortly after getting married, enabling her to enter the cash economy after a period spent working as a domestic labourer for her mother (see above). Women in Kampala did not hesitate to leave relationships that left them 'sitting at home'. Agnes and Joan both separated from their spouses between 2013-2014, and our research team noted how their material circumstances had improved during the third round of interviews in 2015. Joan had discovered that her husband had 11 other children and had been spending a proportion of their household income on sports betting. 
The interdependency between marriage and entrepreneurship was further illustrated by entrepreneurs' sources of start-up capital. Half of our participants (6) listed their spouses as the main source of their start-up capital, followed by their mothers (2), fathers (1), brothers (1), friends (1) and own savings (1). Conspicuous by their absence from this list were NGOs and formal financial institutions. Indeed, many participants were concerned about borrowing from high street banks:

When we go to banks they have a lot terms and conditions they put on their money and they scare us as potential borrowers. They can easily take away the property we bought long ago with our savings. We ask ourselves; are they helping us to develop in that way? (Rose)

Similarly, Mariam asserted that she 'feared' to get a loan and has seen 'people being arrested because of loans', while Hadija emphasised that she had lost weight due to business debts: 'if I add a loan, I think I would just die'. These concerns illustrate some of the emotional pressures associated with formal micro-credit facilities, which ranged from homelessness to imprisonment (Bateman 2014). They also applied to Savings and Credit Cooperatives (SACCOs), which had started to demand significant collateral from members to prevent them 'running away from the area' (Hadija). The government of Uganda has previously encouraged lending through SACCOs with annual interest rates of between 913\% (AMFIU 2015).

Within this context, participants turned to alternative sources of capital including Rotating Savings and Credit Associations (ROSCAs), marriage and family relations. ROSCAs were predominantly organised at the neighbourhood level, providing access to small amounts of money on a weekly or monthly basis. Like family members and spouses, ROSCAs were seen to provide access to 'friendly loan[s] with no collateral' (Hadija). Rather than impersonal legal contracts, such loans were regulated by personal relationships with people who had an intimate knowledge of a borrower's aspirations and obligations, and were therefore more flexible to the volatilities of entrepreneurial life in Kampala.

The reliance of many women in Uganda on marriage as a means to generate the resources necessary to start a business should thus be contextualised in relation to the failings of the formal financial sector. Nevertheless, spousal relations also provided significant entrepreneurial opportunities for some participants. For example, Rose, who had previously been evicted by her first husband and was critical of bank loans (see above) started her own enterprise after establishing a relationship with a supplier while working for her aunt's poultry feed business:

One of the men who were advising me started an affair with me and advised me to increase my stock with his support so as to benefit more from the business. My business started expanding to the extent that I was in position to construct my first house. (Rose)

Here, Rose's personal relationship with a supplier enabled her to access extended lines of credit, facilitating the launch and expansion of her business. At the time of our re-visit in 2015 , she had held a formal introduction ceremony, funded by her business. However, by the same token, the decline of spousal relations also often acted as a precursor to entrepreneurial decline. For example, Janet, who had started a cooked food business with the assistance of her husband in 2012, became divorced in 2014 while two months pregnant. She explained in 2015: 'it is difficult because I no longer get money to inject into the business from home.' 
Our participants often sought to resolve debts and expenditures in the household through the enterprise and vice-versa, driving a constant conversion of assets and capital:

There are times I fall sick and use all of my business capital for medical expenses. When I am discharged I go back to resume business without a single shilling. I rent this place out and sit at home... Sometimes we fail to get meals. [My husband] sometimes leaves behind 5,000 USh (US\$1.43). I then spend 2,000 USh and save 3,000 USh until I raise enough to pay rent and go back to work. I also sell some of my assets [TV, radio, electric fan] and use the money as capital (Aidah)

Aidah's testimony is illustrative of the importance of understanding households and enterprises as 'deeply interconnected sites' in society (McDowell 2004: 147). In the context of Kampala, assets with high levels of liquidity - such as televisions, and other portable goods for which there is a constant demand - are valuable insofar as they can be used to resolve domestic and business debts at short notice. Entrepreneurship may be understood here as an iterative process through which capital is transferred between the household and enterprise in ways that facilitate valued forms of social reproduction. In Aidah's case, the cost of healthcare (rather than financial credit) in Uganda acted as a constraint on her entrepreneurship, leaving her 'sit[ting] at home'.

Critical to the launch phase of any enterprise is the raising of capital. In the Ugandan context, we have seen that while (female) extended family networks provided important opportunities for mobility and training, would-be female entrepreneurs were often reliant on spouses when seeking to raise the money to start a business. Our participants expected their partners to actively support their business activities, and often assessed them in terms of their material contributions. Scholars have noted that female entrepreneurs often require assistance from 'big men' in Ghana (Langevang 2008), and supportive partners in the UK (Ekinsmyth 2011). However, less has been written about the instrumentalisation of marriage as an entrepreneurial strategy (or 'job'). In contrast to 'Mumpreneurs' in the UK, women in Kampala developed business plans prior to marriage, rather than the other way around (ibid.).

Two implications emerge from this observation. First, rather than outright independence, female entrepreneurs in Uganda sought to cultivate forms of productive dependency through which they were able to accumulate and redistribute resources in ways that enabled valued forms of social reproduction. Second, rather than separate domains of life, the household and the enterprise were understood as deeply connected institutions, such that it was logical for women to seek success in their business through their (marital) household and vice-versa. Marriage was thus seen as an ambivalent institution that could facilitate the entrepreneurial activities of women at certain times (launch) and restrict it at others (post-launch).

\subsection{Post-launch: the role of colleagues}

Following the launch of their enterprises, our participants experienced a number of barriers to development and expansion. One of the most significant of these barriers was the burden of unpaid domestic labour. This burden was particularly acute following the birth of children. As Regina explained:

My problem is that in the morning I prepare the children and they go to school... I go to the city centre to buy items... I might leave the city at $1 \mathrm{pm}$, then I collect the child from school. When I bring him home then I clean the table, and clean the items [to sell at her stall]. I can display them up to $4 \mathrm{pm}$... yet I have not yet eaten anything... then I light the charcoal stove and cook until 9pm or 9:30pm. (Regina) 
The increased participation of women in the cash economy in Kampala appeared to have had little impact on gendered divisions of reproductive work, in line with findings in other sub-Saharan African contexts (Chant 2014; Evans 2016), leading to a 'concurrent demise' in women's roles as entrepreneurs and mothers (Langevang et al. 2015: 468). Wealthier women were able to employ younger female relatives to provide childcare, encouraging the migration of the next generation of women to Kampala. However, husbands did not always encourage such forms of support. For example, Agnes explained that after losing her maid, her husband suggested that she stop working in order to stay at home and look after their child herself. Similarly, prior to separating from her husband, Janet switched from a market stall to a less profitable home-based dairy business in order that she may complete 'domestic chores' and look after their children. Such examples illustrate the importance of situating entrepreneurship within the life course of female entrepreneurs.

In the absence of supportive partners, women in Kampala turned to a broad variety of female networks and institutions in order to reduce the burden of reproductive labour and maintain their enterprises. As Scovia emphasised: 'giving birth, like working in a salon business, cannot be done alone'. Scovia was able to keep her salon business open during and immediately after her most recent pregnancy by relying on her friends and colleagues, who ran the business on her behalf until she was able to return. Other participants were supported by women's groups and associations. For example, Juliet started a group with other female business owners called Tulibumu ('Togetherness'), which functioned as a gift circle that provided household gifts and labour to a different member each month, enabling them to spend more time working in their businesses.

Separated women generally faced greater challenges when seeking to balance the demands of entrepreneurship with childcare. For example, Aidah and Joan received no financial support from their ex-partners towards the care and education of their children. So widespread were such cases that one of the central marketplaces in Kampala had established an all-female disciplinary committee dedicated to the mediation of school fee disputes. The committee had successfully acquired contributions from absent fathers in the past after threatening to suspend them from the market. Such institutions served to break down gender boundaries in Kampala by shifting "intimate forms of domestic, sociable and work encounters" into the public sphere (Bauman 1989: 178).

Additional and discreet forms of female solidarity and support were also in evidence. For example, after leaving her husband in 2014 (see above), Joan established a new household with another single mother and business owner in order 'to share resources'. Joan provided childcare during the day, and her colleague at night, enabling Joan to work in the early-morning wholesale market. Further to this, she continued to provide shelter and care for some of the children from her ex-husband's previous marriages. She explained of one of her step-children:

I created a good relationship with his mother and at times she even sends money for his upkeep and school fees, rather than getting it to his father. (Joan)

In this way, female entrepreneurs invested in 'egalitarian multilateral relations' with colleagues, neighbours and step-wives in ways that enabled them to manage uneven divisions of paid and unpaid labour in similar fashion to the banakyeombekedde of precolonial Buganda (Obbo 1980).

While spouses and relatives were influential in the establishment of the first enterprise (see above), subsequent business ventures were often inspired by more experienced 
female entrepreneurs in Kampala, who acted as business mentors. For example, Regina explained her decision to start a new business between our visits in 2012 and 2013:

I had a friend of mine who used to work in the market of Nakawa. She used to sell these items [plastic containers]. I asked her: 'Maama Sharon, if I start my business from our place will it work?' She told me: 'it will work'. I am the first person to start this nature of business in Mutungo here and as I talk people have started setting up businesses of a similar kind... She is the one who taught me (Regina)

Regina's business thus resulted from her identifying an opportunity to extend an economic activity (the sale of plastics) from a city market to a suburb. Critically, however, this venture was made possible by the support of a mentor (as opposed to a spouse) in the same sector, who was able to provide training and connections to wholesalers. Participants often drew upon idioms of kin ('maama'; 'sister') when describing their relationships with neighbours and colleagues. Rather than 'egalitarian multilateral relations', such terms were suggestive of the existence of vertical systems of reciprocal obligation in Kampala through which inexperienced entrepreneurs received advice and support from their senior counterparts (see also Monteith 2018). ${ }^{14}$

One third of our participants changed their main business activity during the three-year panel, while half moved business premises; a finding that supports the emphasis on churning and flux in the literature on female entrepreneurship in the Global South (Lyons \& Snoxell 2005a). The prevalence of such changes - which attest to the importance of longditudinal methodologies - bring into question linear models of the entrepreneurial cycle, through which businesses advance unidirectionally from launch to expansion. The testimonies of our participants in Kampala demonstrate the significance of entrepreneurial experimentation and (re)cycling as processes through which businesses both develop and regress. Rather than starting again, female entrepreneurs brought existing relationships (and forms of embeddedness) with them into new ventures, illustrating the significance of the 'life course' dimension of the entrepreneurial life course approach.

However, there were also limits to the forms of social support and solidarity experienced by female entrepreneurs. Urban marketplaces in Kampala have become increasingly competitive spaces in recent years in which 'strangers skilfully intrude into one's life' (De Boeck \& Plissart 2004: 189 cited Monteith 2018: 12). For example, in the time between our visits in 2013 and 2015, Agnes closed her clothing business after being evicted from her market premises market by her landlord during a trip to Rwanda. Similarly, Regina had initially agreed to rent a stall in Nakawa market after making a payment to the (predominantly male) market leadership, before being ejected by another market vendor who claimed: 'this place is mine and you will not work from it'.

Jealousy was understood to be an important dimension of entrepreneurial life in Kampala that required careful management. As Monica explained:

\footnotetext{
14 There was also evidence of the commercialisation of such services through the establishment of informal markets for skills and knowledge production. For example, in the absence of a social network that provided access to tailoring skills, Janet paid an experienced tailor USh 300,000 (US\$86) to teach her how to improve her sewing so that she could produce more elaborate products for her customers.
} 
In Kampala, when someone sees you have developed they become jealous, they decide to bewitch you so that you do not get customers... So I am planning to keep them [chickens] in the village. (Monica)

Participants were generally wary of the risks of conspicuous forms of accumulation in and around their businesses. For example, when we re-visited Rose in 2015, who had established a successful chicken feed business with the assistance of a partner, she explained that she subsequently lost most of her stock due to a fire that was believed to have been started to conceal a theft. Where significant profits were generated, they were often sent to (predominantly female) extended family via Mobile Money and held in the village in the form of livestock, land or rental property. ${ }^{15}$ These findings underline the importance of understanding entrepreneurship as a relational process that connects peoples and places far beyond the (sub)urban household and enterprise (Hanson 2009).

The reluctance of female entrepreneurs to disclose their profits also extended to the domestic sphere. For example, Miriam described her relationship with her husband:

When I make a loss at my work I tell him and he gives me some money to support the business, but I don't tell him that I have savings somewhere [laughs]... Most of the things I buy are at my Mum's place [goats, chickens]; I give money to my mum and she buys them. At my husband's home, maybe I buy some cups or plates if they get broken, but nothing much. (Miriam)

The reluctance of women to disclose their income to their partners was arguably a product both of high rates of marital breakdown, and the reluctance of men to contribute towards the costs of childcare and education (see above). Miriam's testimony demonstrates that the integration of enterprise and marital household was not an irreversible process, but was rather accelerated during certain phases (launch) and slowed and even reversed during others (post-launch). During the latter phase, female entrepreneurs sought to protect their earnings against the potential failure of both their marriage and their business, while investing in goods that enabled them to maintain connections to their extended families; a logical decision that arguably restricted the expansion of their enterprises. By investing their profits back into their families, female entrepreneurs completed an entrepreneurial cycle that often started with the assistance of these same family members. This point underlines the importance of an entrepreneurial life course perspective that brings into view critical forms of support and influence in the years that precede the establishment of their first enterprise.

We have seen that women were generally able to overcome the barriers to their entrepreneurship during the pre-launch and launch phases, to the extent that the 'average' entrepreneur in Uganda is female (Rosa 2014). However, the barriers to developing and expanding their businesses were more substantial in the post-launch phase owing to the double burden of paid and unpaid labour (particularly once women combined entrepreneurship with motherhood), the gendered insecurities of the rental market, and the difficulties of raising additional capital. As a result of these barriers, female entrepreneurs often cycled between different commercial spaces and activities rather than expanding their original enterprises, in line with the findings of Lyons and Snoxell (2005a). The post-launch phase was thus often truncated and proceeded by the launch of a new business venture.

\footnotetext{
15 James Ferguson (1999) has written of the role of livestock in enabling urban migrants to maintain a symbolic status in the village while working and living in the city.
} 
Our participants sought to manage the insecurities of the post-launch phase by establishing and investing in non-familial support networks with female colleagues and neighbours. These networks enabled the (re)distribution of essential household goods and labour. Significantly, they also facilitated the erosion of male authority by shifting domestic concerns - such as the care and education of one's children - into the public sphere. By drawing on idioms of kin, female entrepreneurs sought to socialise and domesticate commercial relations in Kampala, providing them with a degree of stability in the context of a volatile market economy.

\section{Conclusions}

For many young women in Uganda, entrepreneurship starts and ends with family. The entrance of young women into the urban economy was generally negotiated through relationships with mothers and aunts, who, alongside children, were also the primary beneficiaries of their entrepreneurial activities. Rather than economic independence, the objective of many female entrepreneurs was a form of productive dependency through which they were able to accumulate and redistribute resources in ways that were conducive to valued forms of social reproduction, including the education of their children and the care of their elders.

Scholars have paid considerable attention to the (constrained) ability of young men to conform to the role of provider in Africa and beyond (Ferguson, 2015; Honwana, 2012). However, this role was clearly also important for women in Kampala, for whom business was understood as a fundamental part of being a woman and a mother (as illustrated by their critique of 'sitting at home'). Although present in the region since the precolonial era (Davis 2000; Obbo 1980), the association between business and motherhood has been accentuated by the marketisation of reproductive spheres of the economy (e.g. education, housing and healthcare) since the 1970s, which has required Ugandan women to take on the double burden of paid and unpaid work.

Between the maintenance of their businesses and the support of their families, female entrepreneurs were dependant on a number of additional forms of assistance at different stages of their entrepreneurial life course. While entrepreneurship was initially seen as an alternative to marriage for many young women in Uganda, the launching of an enterprise was an activity that often depended on spousal support, and so women frequently instrumentalised marriage as part of a longer-term entrepreneurial strategy. Following the establishment of their businesses, they invested in relationships with partners, neighbours, colleagues, mentors and step-wives, and joined all-female associations and institutions.

While relationships with spouses were commercialised through references to material contributions, those with neighbours and colleagues were domesticated through idioms of kin. Female entrepreneurship in Kampala thus involves the simultaneous commercialisation of social relations, and the socialisation of commercial relations, through the institution of the household-enterprise. On the one hand, these entrepreneurial relations and networks were necessitated by the rising economic costs of a gendered division of reproductive labour that has gone largely unchallenged since the colonial era. However, on the other hand, they served to destabalise this division of labour by shifting "intimate forms of domestic, sociable and work encounters" into the public sphere (Bauman 1989: 178).

These findings consolidate existing work on the social and familial embeddedness of female entrepreneurship (Ekinsmyth 2009; Langevang et al. 2012; 2015). However, they also extend this work by demonstrating the value of an 'entrepreneurial life course' 
perspective for revealing the temporal dimension of female entrepreneurship. This perspective is critical to understanding, for example, the ways in which marriage can facilitate female entrepreneurship during certain phases of the entrepreneurial cycle (launch) and restrict it during others (post-launch and expansion). The volatile relationship between entrepreneurship and marriage, in particular, poses a challenge to the spatial and temporal stability that is often implied in the family embeddedness literature in the global North. 


\section{References}

Ahikire, J., \& Ampaire, C. (2003). Vending in the City: A Gendered Perspective (CBR Working Paper Series). CBR Working Paper Series. Kampala.

Aldrich, H. E., \& Cliff, J. E. (2003). The pervasive effects of family on entrepreneurship: toward a family embeddedness perspective. Journal of Business Venturing, 18(5), 573-596. https://doi.org/10.1016/S0883-9026(03)00011-9

Bantebya-Kyomuhendo, G., \& McIntosh, M. (2006). Women, Work and Domesrtic Virtue in Uganda 1900-2003. London: James Currey.

Baron, R. A. (2007). Entrepreneurship: a process perspective. In J. R. Baum, M. Frese, \& R. . Baron (Eds.), The Psychology of Entrepreneurship. Mahwah, NJ: Erlbaum.

Bhattacharya, S. (2014). Is labour still a relevant category for praxis? Critical reflections on some contemporary discourses on work and labour in capitalism. Development and Change, 45(5), 941-962. https://doi.org/10.1111/dech.12123

Bird, B., \& Brush, C. (2002). A gendered perspective on organizational creation. Entrepreneurship: Theory and Practice, 26, 41-65.

Blake, M. K. (2006). Gendered lending: Gender, context and the rules of business lending. Venture Capital, 8(2), 183-201. https://doi.org/10.1080/13691060500433835

Chant, S. (2014). Exploring the "feminisation of poverty" in relation to women's work and home-based enterprise in slums of the Global South. International Journal of Gender and Entrepreneurship, 6(3), 296-316. https://doi.org/10.1108/IJGE-092012-0035

Chen, M. A. (2001). Women and Informality: A Global Picture, the Global Movement. SAIS Review, 21(1), 71-82.

Chen, M., Roever, S., \& Skinner, C. (2016). Editorial: Urban livelihoods: reframing theory and policy. Environment and Urbanization, 28(2), 1-12. https://doi.org/10.1177/0956247816662405

Chirwa, E. W. (2008). Effects of Gender on the Performance of Micro and Small Enterprises in Malawi. Development Southern Africa, 25(3), 347-362. https://doi.org/10.1080/03768350802212139

Clark, G. (1994). Onions Are My Husband: Survival and Accumulation by West African Market Women. Chicago: University of Chicago Press.

Davis, P. J. (2000). On the sexuality of "town women" in Kampala. Africa Today, 47(3), $29-60$

De Mel, S., Mckenzie, D., \& Woodruff, C. (2009). Are Women more Credit Constrained? Experimental Evidence on Gender and Microenterprise Returns. American Economic Journal: Applied Economics, 1(3), 1-32.

Di Nunzio, M. (2015). What is the Alternative? Youth, Entrepreneurship and the Developmental State in Urban Ethiopia. Development and Change, 46(5), 11791200. https://doi.org/10.1111/dech.12187

Ekinsmyth, C. (2011). Challenging the boundaries of entrepreneurship: The spatialities and practices of UK "Mumpreneurs." Geoforum, 42(1), 104-114. https://doi.org/10.1016/j.geoforum.2010.10.005

Evans, A. (2016). The Decline of the Male Breadwinner and Persistence of the Female Carer: Exposure, Interests, and Micro-Macro Interactions. Annals of the American Association of Geographers, 106(5), 1135-1151. https://doi.org/10.1080/24694452.2016.1184557

Ferguson, J. (1999). Expectations of Modernity: Myths and Meanings of Urban life on the Zambian Copperbelt. Berkeley, Calif.: University of California Press.

Ferguson, J. (2015). Give a Man a Fish: Reflections on the New Politics of Distribution. Durham and London: Duke University Press.

Fraser, N. (2014). Beyond Marx's Hidden Abode: For an Expanded Conception of Capitalism, 55-72.

Frayne, B. (2004). Migration and urban survival strategies in Windhoek, Namibia. 
Geoforum, 35(4), 489-505. https://doi.org/10.1016/j.geoforum.2004.01.003

Frese, M., \& Gielnik, M. M. (2014). The Psychology of Entrepreneurship. The Annual Review of Organizational Psychology and Organizational Behavior, 1, 413-438. https://doi.org/10.1007/978-3-319-64304-5_8

Ganle, J. K., Afriyie, K., \& Segbefia, A. Y. (2015). Microcredit: Empowerment and disempowerment of rural women in Ghana. World Development, 66, 335-345. https://doi.org/10.1016/j.worlddev.2014.08.027

Gibson-Graham, J. K. (1996). The End of Capitalism (as we knew it): A Feminist Critique of Political Economy. Oxford: Blackwell.

Global Entrepreneurship Research Association. (2017). Global Entrepreneurship Monitor - Global Report 2016/17, 180. https://doi.org/10.1017/CB09781107415324.004

Gough, K. V, Langevang, T., \& Owusu, G. (2013). Youth employment in a globalising world. International Development Planning Review, 35(2), 91-102. https://doi.org/10.3828/idpr.2013.7

Granovetter, M. (1985). Economic Action and Social Structure: The Problem of Embeddedness. American Journal of Sociology, 91(3), 481-510. Retrieved from http://www.jstor.org/stable/10.2307/2780199

Grimm, M., Hartwig, R., \& Lay, J. (2013). Does Forced Solidarity Hamper Investment in Small and Micro Enterprises? IZA Discussion Paper No. 7229, (7229).

Hamilton, E. (2013). The discourse of entrepreneurial masculinities (and femininities). Entrepreneurship and Regional Development, 25(1-2), 90-99. https://doi.org/10.1080/08985626.2012.746879

Hanson, K. T. (2005). Landscapes of survival and escape: Social networking and urban livelihoods in Ghana. Environment and Planning A, 37(7), 1291-1310. https://doi.org/10.1068/a3750

Hanson, S. (2009). Changing places through women's entrepreneurship. Economic Geography, 85(3), 245-267. https://doi.org/10.1111/j.1944-8287.2009.01033.x

Harriss-White, B. (2010). Work and Wellbeing in Informal Economies: The Regulative Roles of Institutions of Identity and the State. World Development, 38(2), 170-183.

Harriss-White, B. (2014). Labour and petty production. Development and Change, 45(5), 981-1000. https://doi.org/10.1111/dech.12124

Hlady-Rispal, M., \& Jouison-Laffitte, E. (2014). Qualitative research methods and epistemological frameworks: A review of publication trends in entrepreneurship. Journal of Small Business Management, 52(4), 594-614.

Honwana, A. M. (2012). The Time of Youth: Work, Social Change, and Politics in Africa. The Time of Youth: Work, Social Change, and Politics in Africa, 39(3), 554-557. https://doi.org/10.1080/02533952.2013.849404

Jack, S. L., \& Anderson, A. R. (2002). The effects of embeddedness on the entrepreneurial process. Journal of Business Venturing, 17, 467-487.

Jayawarna, D., Rouse, J., \& Kitching, J. (2013). Entrepreneur motivations and life course. International Small Business Journal, 31(1), 34-56. https://doi.org/10.1177/0266242611401444

Journal, A. I., Jayawarna, D., Rouse, J., \& Macpherson, A. (2014). Life course pathways to business start-up. Entrepreneurship \& Regional Development. Taylor \& Francis. https://doi.org/10.1080/08985626.2014.901420

Kuada, J. (2009). Gender, Social Networks, and Entrepreneurship in Ghana. Journal of African Business, 10, 85-103.

Langevang, T. (2008). "We are managing!" Uncertain paths to respectable adulthoods in Accra, Ghana. Geoforum, 39(6), 2039-2047. https://doi.org/10.1016/j.geoforum.2008.09.003

Langevang, T., \& Gough, K. V. (2012). Diverging pathways: young female employment and entrepreneurship in sub-Saharan Africa. The Geographical Journal, 178(3), 242-252. 
Langevang, T., Gough, K. V, Yankson, P. W. K., Owusu, G., \& Osei, R. (2015). Bounded Entrepreneurial Vitality: The Mixed Embeddedness of Female Entrepreneurship. Economic Geography, 91(4), 449-473. https://doi.org/10.1111/ecge.12092

Langevang, T., Namatovu, R., \& Dawa, S. (2012). Beyond necessity and opportunity entrepreneurship: motivations and aspirations of young entrepreneurs in Uganda. International Development Planning Review, 34(4), 439-460. https://doi.org/10.3828/idpr.2012.26

Lyons, M., \& Snoxell, S. (2005a). Creating Urban Social Capital : Some Evidence from Informal Traders in Nairobi, 42(7), 1077-1097.

Lyons, M., \& Snoxell, S. (2005b). Sustainable Urban Livelihoods and Marketplace Social Capital : Crisis and Strategy in Petty Trade, 42(8), 1301-1320.

Mabogunje, A. L. (1990). Urban Planning and the Post-Colonial State in Africa: A Research Overview. African Studies Review, 33(2), 121-203.

Mcdowell, L. (2004). Work, workfare, work/life balance and an ethic of care. Progress in Human Geography, 28(2), 145-163. https://doi.org/10.1191/0309132504ph478oa

Meagher, K. (2005). Social capital or analytical liability? Social networks and African informal economies. Global Networks-a Journal of Transnational Affairs, 5(3), 217238.

Meagher, K. (2011). Informal Economies and Urban Governance in Nigeria: Popular Empowerment or Political Exclusion? African Studies Review, 54(2), 47-72. https://doi.org/10.1353/arw.2011.0026

Minniti, M., \& Naudé, W. (2010). Introduction: What Do We Know About The Patterns and Determinants of Female Entrepreneurship Across Countries? European Journal of Development Research, 22(3), 277-293. https://doi.org/10.1057/ejdr.2010.17

Monteith, W. (2018). Showing 'heart' while making money: negotiating proximity in a Ugandan marketplace. Africa, 88(S1), S12-S30. https://doi.org/10.1017/S0001972017001127

Monteith, W., \& Giesbert, L. (2016). 'When the stomach is full we look for respect: Perceptions of 'good work in the urban informal sectors of three developing countries. Work, Employment \& Society, (Online Fi. https://doi.org/10.1177/0950017016650606

Morduch, J. (2000). The microfinance schism. World Development, 28(4), 617-629. https://doi.org/10.1016/S0305-750X(99)00151-5

Musisi, N. (1995). Buganda women's night market activities. In African market women and economic power (pp. 121-139). Westport Conn: Greenwood Press.

Nicholson, L., \& Anderson, A. R. (2005). News and nuances of the entrepreneurial myth and metaphor: Linguistic games in entrepreneurial sense-making and sense-giving. Entrepreneurship: Theory and Practice. https://doi.org/10.1111/j.1540$6520.2005 .00074 . x$

Ntseane, P. (2004). Being a female entrepreneur in Botswana: Cultures, values, strategies for success. Gender and Development, 12(2), 37-43. https://doi.org/10.1080/13552070412331332180

Obbo, C. (1980). African Women: Their Struggle for Economic Independence. London: Zed Books.

Oberhauser, A. M. (2002). Relocating gender and rural economic strategies. Environment and Planning A, 34(7), 1221-1237. https://doi.org/10.1068/a34224

Parkin, D. J. (1969). Neighbours and Nationals in an African City Ward. University of California Press.

Ramírez Pasillas, M., Brundin, E., \& Markowska, M. (2017). Contextualizing entrepreneurship in emerging economies and developing countries. Cheltenham: Elgar.

Rosa, P. (2014). Uganda country profile. Retrieved January 10, 2018, from https://www.gemconsortium.org/country-profile/117 
Schoon, I., \& Duckworth, K. (2012). Who becomes an entrepreneur? Early life experiences as predictors of entrepreneurship. Developmental Psychology. https://doi.org/10.1037/a0029168

Shacklock, G., \& Thorp, L. (2004). Life History and Narrative Approaches. In B. Somekh \& C. Lewin (Eds.), Research Methods in the Social Sciences (pp. 156-163). London: SAGE.

Simone, A. M. (2004). For the city yet to come: changing African life in four cities. Durham N.C.: Duke University Press.

Singer, S., Amorós, E., \& Moska, D. (2015). Global Entrepreneurship Monitor - 2014 Global Report.

Snyder, M. (2000). Women in African economies. From burning sun to boardroom. Business ventures and investment patterns of 74 Ugandan women. Kampala: Fountain Publishers Ltd.

Staples, J. (2014). Leprosy and a Life in South India: Journeys with a Tamil Brahmin. Minneapolis: Lexington Books.

van Rooyen, C., Stewart, R., \& de Wet, T. (2012). The Impact of Microfinance in SubSaharan Africa: A Systematic Review of the Evidence. World Development, 40(11), 2249-2262. https://doi.org/10.1016/j.worlddev.2012.03.012

Wallman, S. (1996). Kampala Women Getting By: Wellbeing in the time of AIDS. London: James Currey.

Wallman, S., \& Pons, V. (2001). Where Have All The Young Men Gone? Evidences and Explanations of Changing Age: Sex Ratios in Kampala. Africa, 71(1). https://doi.org/10.3366/afr.2001.71.1.113

Weiss, B. (2009). Street Dreams and Hip Hop Barbershops: Global Fantasy in Urban Tanzania. Bloomington: Indiana University Press.

World Bank. (2012). World Development Report 2013: Jobs. Washington DC.

World Bank. (2013). Uganda Economic Update. Jobs: Key to Prosperity. Washington DC. 